\title{
The mismeasure of Capital: a response to McCloskey
}

\author{
STEVEN PRESSMAN \\ Colorado State University
}

\begin{abstract}
This paper is a response to Deirdre McCloskey's review essay, published recently in this journal, of Thomas Piketty's Capital in the twenty-first century. It argues that McCloskey has set up a number of straw men to attack. Furthermore, her three main arguments against Piketty are flawed. McCloskey wants human capital to be added to Piketty's measure of wealth; she contends that Piketty does not understand the supply-response mechanism; and she accuses Piketty of focusing on the wrong problem-inequality rather than poverty. This paper explains why these are all bad arguments.
\end{abstract}

Keywords: income inequality, McCloskey, Piketty, redistribution, wealth inequality

JEL Classification: D31, D63, B41

\section{INTRODUCTION}

I have known Deirdre McCloskey for a long time. We used to go drinking at the annual History of Economics Society conferences (beer not wine) in the 1980s. After publication of The rhetoric of economics (McCloskey 1985), I wrote a rather critical piece in the Eastern Economic Journal (Pressman 1987) that elicited a "disagreeable" response from McCloskey (1987). My main point was that there was a difference between rhetoric and the actual argument, and that we should focus on what is important-the argument. Rhetoric is there only to remind us of the argument. Tjalling Koopmans made a similar point when he asserted that he intentionally wrote badly so that he would not gain an unfair advantage in the marketplace of ideas (Samuelson 1988). Anyone who has tried reading Koopmans can testify to the veracity of this statement. Despite his poor rhetoric, Koopmans had a good case. In her superb book on rhetoric McCloskey pointed out that, contra Koopmans, how

AUTHOR'S NOTE: The author thanks the editor and three anonymous referees for their helpful comments on an earlier version of this paper. All remaining errors are the responsibility of the author. 
arguments are presented is important; nonetheless, good rhetoric is no substitute for a sound argument.

The review essay of Capital in the twenty-first century (hereafter Capital) by Thomas Piketty (2014), recently published in this journal, is typical McCloskey. On the one hand, it is well-written, clever, and erudite. Rhetorically it is a gem. Just as Piketty peppers his book with references to the novels of Jane Austin and Honoré Balzac, McCloskey makes reference to Aristotle, to Stephen Hawking, and to Anthony Trollope's delightful political novel Phineas Finn. On the other hand, the paper is poorly argued and filled with straw men.

Overall, McCloskey finds Capital "honest and massively researched" but flawed because it does not understand "a key piece of economics" and because of a "fundament ethical problem in the book" (McCloskey 2014, 94; future references to this work will just contain page numbers). Section 2 below discusses some of the many straw man arguments in the paper. Section 3 then addresses the substantive issues raised by McCloskey. Section 4 concludes.

\section{STRAW MAN ARGUMENTS}

Because McCloskey's paper is loaded with straw man arguments I spent some time in the previous section discussing rhetoric. Like Socrates and Plato, I am bothered by a sole focus on rhetoric. Good rhetoric helps us remember key points, but good rhetoric is no substitute for good argumentation. Unfortunately, McCloskey's review contains many rhetorical flourishes that do not address the main arguments of Capital. Many are straw men, erected to cast doubt on the analysis and the policy prescriptions of Piketty. They hinder, rather than aid, an understanding of Piketty. We address a handful of these straw men here.

First, McCloskey (75) claims the book contains "leftish worries" about capitalism, something with a long history in economics. She cites the concerns of Malthus about land scarcity and the worries of Ricardo about landowners usurping the national surplus, leaving little for investment and improving living standards. J.S. Mill is accused of worrying about the stationary state being just around the corner. McCloskey (79) contends that these leftists see capitalism as seriously defective and fail to understand its many benefits. She even adds to her list of leftist concerns the worries that many people have about the 
environment. McCloskey (81) concludes by accusing Piketty of setting forth a pessimistic message because pessimism sells.

This entire line of attack is rather baffling. How anyone could accuse Malthus of being a leftist is hard understand. Malthus opposed all forms of government aid to the poor. Instead of supporting peasants or laborers, he defended the interests of wealthy landowners. Nor is Ricardo a notorious lefty. He defended the same capitalist interests that McCloskey (2006) champions. Mill wrote about the stationary state for the same reasons that other classical economists did-this was the logical conclusion of Ricardo's corn model. And Mill was not pessimistic; he sought to explain how and why the stationary state might be desirable. As for fears about the environment, it is hard to see this as some left-wing plot. It expresses human concerns about the future of mankind. Little is more conservative than wanting to maintain life, as we know it, on our planet.

Furthermore, it is not clear that pessimism sells. In fact, optimism typically sells. Self-help books are extremely popular. Ronald Reagan's optimism helped him win the US presidency. And while it is hard to evaluate the claim that a work is pessimistic in tone or nature, a good case can be made that Capital is not a pessimistic tome. Yes, it recognizes some problems with capitalism. However, after the Great Recession, most people recognize that there may be problems with capitalism. Yet Piketty does not just point out these problems, which would lead to a pessimistic work by most accounts. At the end of his book he suggests several policy solutions to remedy the problems that he identifies earlier. The last part of Capital talks about fiscal and monetary policy as well as a wealth tax. Overall, Piketty's vision is close to that of John Maynard Keynes. Like Keynes, Piketty recognizes the benefits of capitalism, but also that problems can arise under capitalism. He seeks to make life better under capitalism so that we don't kill the goose that lays the golden eggs. This is a rather hopeful message.

Second, McCloskey (83) notes that in a broad array of countries it is true that r>g during the 20th century; however, in some of them (e.g., Germany, France and Sweden) post-tax and post-transfer inequality did not rise inexorably during the late 20th century. McCloskey is correct that in some nations inequality has increased very little, if at all. But this is not because Piketty is wrong about $r>g$. Piketty is clear that $r>g$ holds for pre-tax income only. After-tax differences arise because some 
countries use government policy to keep r $>$ g from pushing up post-tax and post-transfer inequality-for example, the progressive tax policies that Piketty advances at the end of Capital. High marginal tax rates can also affect the pre-tax distribution of income, not only by affecting work incentives but also because they affect the incentive to extract rents.

Third, McCloskey attributes to Piketty a moral philosophy that amounts to no more than "I don't like inequality". Or, as McCloskey (86) sarcastically summarizes this view: "that is bad [...] is his ethical philosophy in full". Indeed, this line is quite memorable; it is wonderful rhetoric. But it is also a straw man. Piketty is clearly worried about the economic consequences of inherited wealth-what this means for people's standard of living now as well as what it means for the standard of living of our children and grandchildren. He fears the return of the rentier, whose wealth generates few incentives for the wealthy to work (Piketty 2014, 113-115). This lowers current living standards and deprives us of innovations due to these individuals and the resultant increase in future living standards from them. Finally, the last part of Capital is an argument for a wealth tax to mitigate the problem of rising inequality. A large literature does exist on the negative consequences of inequality (more on this later). McCloskey is right that Capital ignores this. Yet McCloskey ignores this literature as well when she accuses Piketty of only making a moral case against inequality. This literature forms the background to Capital. It needs to be understood as such.

Fourth, McCloskey (90) contends that Piketty $(2014,513)$ does not like high CEO salaries and therefore recommends high marginal tax rates, possibly as high as $80 \%$ on top incomes. McCloskey then argues that if Piketty does not like high incomes, we might as well prohibit them or shame compensation committees into lowering CEO pay. As noted in the paragraph above, Piketty's argument against CEO pay is not a moral argument. Rather, his case is an economic one. The economic argument for high marginal tax rates is well-known. If inequality has large externalities, and if the marginal social benefits of high top tax rates exceed the marginal social costs, there is an economic justification for high rates. Maybe Piketty is right and the benefits exceed the costs until we reach an $80 \%$ marginal tax rate. If this is true, there is no case for a top tax rate of nearly $100 \%$, as McCloskey suggests. There can be empirical arguments about the $80 \%$ figure and whether this is optimal or not. A large literature already exists on this topic stemming from the work of Frank Ramsey (1927) and James Mirlees (1971). However, 
dismissing such literature with the claim that Piketty doesn't like high incomes, and so once we impose high marginal tax rates we might as well set the top tax rate at $100 \%$ or prohibit large CEO compensation, is nothing but a straw man argument.

Fifth, McCloskey (91-92) accuses Piketty of not understanding the difference between shifts in curves and movements along curves. She quotes Piketty $(2014,6)$ as saying: "If the supply of any good is insufficient, and its price is too high, then demand for that good should decrease, which should lead to a decline in its price". When I teach basic supply-and-demand analysis to undergraduates, I do my very best to get students to understand that demand is the curve and quantity demanded is a number. But at times I slip into the usual convention of calling "quantity demanded" just plain old "demand". Piketty does something similar on page 6 , but it is something that most economists do (since we know the difference, there is no confusion). This criticism has nothing to do with Piketty's explanation for rising inequality and it has nothing to do with the viability of his main policy prescription. Rather, it is irrelevant to Piketty's argument, and something designed to make Piketty look bad and cast doubt on the logical argument contained in Capital. It too is a straw man.

Sixth, McCloskey (88) contends that Piketty defines capital as something that is owned only by rich people. As anyone who reads Capital carefully will see, this is not the case. The book documents the rising ownership of wealth by the middle class in the middle part of the 20th century, which then gets reversed in the latter part of the 20th century and into the 21 st century. It also seeks to explain this phenomenon. As Piketty shows, over time the middle class has gained wealth mainly through homeownership, but also through owning some financial assets. His concern is that this process began to reverse itself in the 1980s and that this has continued until today. He next explains why he thinks this trend will continue into the 21st century; then he suggests several policies to mitigate or reverse it. Nowhere does Piketty define wealth as something only rich people possess. However, he does note that (excluding land and housing) the rich today own a very large fraction of national wealth (stocks, bonds, etc.).

\section{SUBSTANTIVE ARGUMENTS}

McCloskey $(74-75,80)$ praises Capital at several points in her review essay. She compliments Piketty for not doing meaningless statistical 
tests of significance and for not engaging in existence proofs-two bugaboos for McCloskey.

Nonetheless, McCloskey's review of Capital is quite negative; and it does more than just engage in straw man arguments. McCloskey raises three substantive arguments against Piketty. First, she thinks that human capital should be added to our measure of wealth. Second, McCloskey (90) argues that Piketty does not understand the supplyresponse mechanism. This applies to the high taxes espoused by Piketty, which would slow economic growth. It also applies to the public policies that Piketty advocates; McCloskey worries about the disincentives these policies would generate, and claims that (contra Piketty) the gains from growth far exceed any gains for average citizens from the redistributive policies that Piketty proposes. Third, there is an argument that Piketty has focused on the wrong problem. Poverty rather than inequality is the important issue, according to McCloskey. We address these three arguments below.

\section{Adding human capital}

For McCloskey (88) human capital is a source of future income. It leads to future wage income just as physical capital leads to dividends, interest and capital gains in the future. For this reason, McCloskey believes, we need to add human capital when we measure wealth. Were we to do this, workers would own more net wealth, perhaps a majority of it. Furthermore, McCloskey claims, adding human capital to wealth would make Piketty's problem (that wealth and income inequality tend to rise over time because $r>g$ ) disappear.

Several problems plague this line of argument.

A first problem is that we lack good measures of human capital, as exist for other forms of wealth. We know the value of stocks and bonds, land and homes, and most other assets that people own. Such information can even be looked up online. It is the information appearing on estate tax returns that Piketty uses to estimate the distribution of wealth (for more on this see Pressman 2015, ch. 3). In contrast, it is not clear how to get data on human capital. Human capital is typically measured in terms of years of experience and/or years of education. But not all years of education and experience are the same; to adjust for this would require using the present discounted value of future income. Besides problems involving the choice of an appropriate discount rate, there is also the problem that future income, especially 
income that will be received far in the future, is unknown and unknowable.

Not only are there measurement issues. Another problem is that human capital is unlike physical capital in one important respect. As Piketty $(2014,46)$ notes, human capital cannot be owned by others or traded on any market. This is the main reason we lack data on human capital. But there are also deeper issues here. If I own a house and don't have sufficient income to support myself and feed my family, I can sell my house and downsize. The extra money from liquidating my wealth will enable my family to survive for several years, maybe much longer. I am unable to do something similar with human capital. I can't sell my college degree to someone else and then use the proceeds to buy food and pay my rent. I can't sell my extensive work experience to someone else so that they can earn more money now. And it is disingenuous to say that I should use my human capital to earn more money. If my income is low, and if I am struggling to pay my bills, my human capital also must be low.

Furthermore, there is a key difference between capital and wealth. In economics, capital is a factor of production; it refers to the plants and equipment used to produce more output. In contrast, wealth includes all the ownership of this capital (through stock ownership and individual ownership of business firms) but also includes other assets owned by households, such as land, rare artwork, government bonds, and assets in bank accounts. Piketty $(2014,47)$, unfortunately, obfuscates this distinction by using the terms interchangeably. He is really interested in wealth; Capital seeks to explain how wealth distribution changes over time and how it leads to income inequality. Given that Piketty is concerned with wealth, it is not clear that we should add human capital to wealth. While human capital may be capital, it is not wealth. My wealth has value because it entitles me to the ownership of things with value-e.g., the plants and equipment of firms, future debt payments on bonds, the ability to withdraw money from a savings account, the ability to rent property or live in a home. My human capital is not like this. It gives me ownership of my future income; but I have always had this (although it will likely increase the amount of my future income). Accumulating more human capital does not provide ownership of anything additional or new.

Finally, there are empirical problems with McCloskey's position. Workers have become more educated and have accumulated more 
human capital on average over time (Goldin and Katz 2008). Human capital theory entails that wage income should increase as a fraction of national income as workers become more educated (Piketty 2014, 22); yet this is not what we see in the actual data. In most developed countries, the capital share of income has been growing for several decades (Piketty 2014, fig. 3.1, 3.2, 4.1, 4.6, and 4.9).

\section{Supply responses: growth and redistribution}

First and foremost, Capital is about inequality. It shows how income and wealth inequality have grown in tandem in numerous countries over a long time period. It analyzes the causes of rising income inequality and sets forth some policy solutions-higher top marginal tax rates and a wealth tax. The strongest argument McCloskey makes in her review essay on Capital concerns the redistributive policies Piketty advances for saving capitalism. McCloskey laments (as noted earlier) that Piketty assumes inequality is bad, and she is afraid that the policies advanced by Piketty would do more harm than good.

McCloskey is right concerning the first point-Piketty does not make a case that there are negative effects of inequality. This is a major gap in his book. But there is a difference between a gap in some argument and a bad argument.

The empirical literature on the macroeconomics of inequality and economic growth seems to have reached a consensus-for developed capitalist nations at least, greater equality is associated with greater economic growth (Alesina and Rodrik 1992, 1994; Benabou 1996; Benner and Pastor 2012; Deininger and Squire 1998; Lundberg and Squire 2003; Ostry et al. 2014; Panizza 2002; Perrotti 1993, 1996; Perrson and Tabellini 1994). This literature has been rather robust, holding true for many measures of inequality, for different time frames and for a number of different nations.

One mechanism by which this might occur is through the impact of inequality on demand. Those with low incomes are more likely to spend their income than save it. This additional spending raises total demand and increases economic growth.

Alternatively, it could be some social-psychological process. The human mind developed over millions of years to deal with specific problems faced by our ancestors foraging in a dangerous and competitive world on the African savannah. Its characteristics are those that best promoted survival in this environment. Above all, our ancient 
ancestors required food on a regular basis; when food was available it needed to be shared somewhat equally. When it was not shared equally, this threatened the survival of some and created great stress. Those people who reacted in ways that enabled them to share in the available food supply; these people were more likely to survive and pass this trait on to their offspring. This involved developing predilections for both trust and reciprocity. According to Zak and Knack (2001), these habits also reduce transaction costs and promote greater growth. Empirical result from the ultimatum game provide support for this. In the ultimatum game, two people divide a fixed sum of money. The first subject can propose any division they like; the second subject can only accept or reject that division. If the division is accepted, each person receives the amount of money proposed by the first subject; if the division is rejected, each person receives nothing. From a standard economic perspective, dividers should propose that they get most of the money; the second subject, faced with a choice of little or nothing, should then choose little over nothing. Many actual experiments have been conducted with individuals playing this game for real stakes. In general, dividers make substantial offers and most people reject unequal offers-despite the fact that it is both costly and irrational (in an economic sense). These results hold even when people split amounts that are the equivalent of several months' pay (Henrich et al. 2001; Kahneman et al. 1986; Klasen 2008).

Finally, we know that inequality creates considerable stress for those lower down on the income ladder (for reasons alluded to above) and that stress leads to health problems, which then affects worker productivity (Wilkinson 1996) and thus economic growth.

Inequality can also directly impact worker productivity. Harvey Leibenstein (1966) coined the term "x-efficiency" to indicate that much worker effort is discretionary, and argued that work effort is difficult and costly to monitor. As such, the pay distribution within a firm can determine employee behavior and productivity. Workers who feel that too much income goes to top executives may work more slowly or less efficiently. Large pay differentials may also increase employee turnover (Gerhart and Milkovich 1992), or lead to vandalism, absenteeism, strikes and other forms of sabotage against the firm. Large pay differentials can also create disincentives for cooperation to the detriment of organizational performance. Substantial research has found that when productivity depends upon team effort, unequal rewards hurt 
productivity (Bloom 1999; Cowherd and Levine 1992; Bloom and Michel 2002).

McCloskey is also right that wealth taxes have a long and checkered history. During medieval times, they financed the Crusades (Hyman 2014, 604). In 1662, King Charles II imposed a tax of one shilling on every fireplace and stove in England and Wales. This can be regarded as a wealth tax since wealthier families typically own bigger homes, with more stoves and fireplaces, and so pay higher taxes than families with smaller homes and fewer fireplaces. Nonetheless, this tax was extremely unpopular because it required tax agents to burst into people's homes unannounced so that fireplaces and stoves would not be covered up right before their wealth was going to be assessed for tax purposes.

The 1696 window tax in England and Scotland replaced the stove tax as a national revenue source. It was based on the number of windows in each home. The logic behind the window tax was similar to that of the stove tax, but it didn't require revenue agents entering people's homes unannounced to count their stoves; windows could be counted from outside the home. As Adam Smith $(1937,798)$ noted, this was not a true wealth tax; many wealthy homeowners in big cities had fewer windows than poor rural families. In addition, the tax had a number of rather undesirable consequences. To reduce their tax obligations many people bricked over their windows. You can still see the effects of this in the UK today-there are many places where you can look up at a building and see the outlines of former windows in a different shade or type of brick. The highly unpopular window tax was finally repealed by Parliament in 1851 (Oates and Schwab 2015).

While the US has shunned an annual tax on aggregate wealth, the same cannot be said of Europe. The modern history of wealth taxation is almost as bad as the history of the fireplace and window taxes. In 1990, one-half of the 34 OECD nations taxed wealth holdings. Over the past quarter century, wealth taxes have been abandoned throughout Europe. By 2000 only one-third of OECD nations were taxing wealth. The parade of nations abandoning wealth taxation continued into the 21 st century. Finland, Iceland, and Luxembourg all repealed their wealth taxes in 2006. Spain did so in 2008 and Sweden followed in 2007. By 2010 only France, Norway, and Switzerland taxed household wealth (Evans 2013)less than $10 \%$ of OECD nations. It is clear that Piketty is swimming against the tide of history. 
McCloskey stands on shakier ground when she opposes other taxes, believing they would do more harm than good. She goes particularly awry when describing the tradeoff between redistribution and growth as some kind of either/or decision. Instead, we face a continuum of options. At one extreme the government can engage in no redistribution at all. This was the policy favored by Malthus. At the other extreme we can redistribute income so that everyone receives the same disposable income.

Arthur Okun pointed out that we can do some redistributing, or find a middle ground between these two extreme positions. He even did a great rhetorical job describing this process as moving income in a leaky bucket from the rich to the poor. He framed the redistribution question in terms of how much leakage we are willing to allow in order to provide some income to those at the bottom of the distribution. Okun $(1975,94)$ thought we should stop when leakages approach 60\%. Certainly, other people will have other intuitions regarding this percentage. John Rawls (1971) would probably stop at something close to 80\%. For McCloskey, $10 \%-20 \%$ would likely be optimal.

We can get a sense of what is involved here by using some data from Piketty. The percentage of total income received by the top $10 \%$ of households has risen from less than 35\% in 1980 to 50\% in 2012. Most of these gains have gone to the top $0,1 \%$, those making more than $\$ 2$ million. With US national income approaching \$16 trillion, this income transfer amounts to nearly $\$ 2,5$ trillion. If the top $0,1 \%$ saves $15 \%-20 \%$ more of its income than average, there will be $\$ 400$ billion to $\$ 500$ billion less spending as a result of rising income inequality. With a multiplier of close to 2, output will be $\$ 800$ billion lower, or more than $4 \%$ of US GDP. To put this into concrete terms, median income in the US would be around $4 \%$ greater if income were distributed as in the postWWII decades, and if this led to more spending and greater economic growth. This is in addition to the income gains accruing to a large majority of the population from having a more equal distribution of income than has existed during the past several decades. Moreover, it is unlikely that redistribution from the top $0,1 \%$ to the rest of the population would reduce income (or productivity) growth by $4 \%$ a year, especially since productivity growth has been growing at $2 \%$ annually for several decades and it grew faster when the top $0,1 \%$ received a smaller share of total income. 
Finally, and perhaps the most disturbing part of McCloskey's argument, may be the assumption that because growth was more important than redistribution in the past for increasing living standards, this must also hold for the future. Even investment prospectuses are required to warn potential investors that past returns are no guarantee of future returns.

Certainly, redistribution was not extensive until the 20th century when the modern welfare state was built. So, looking at the distant past, one sees growth but little or no redistribution. Concluding from this that growth is always more important than redistribution for average citizens is surely mistaken; we cannot generalize from history like this.

One reason we may have a new relationship between economic growth and redistributive efforts may be that productivity growth (and hence economic growth) has declined because we have reached the end of the industrial revolution. In his recent book, Robert Gordon (2016) argues that economic growth in the US from the late 1800s to 1940 was driven mainly by technological breakthroughs from the first industrial revolution. The key inventions that improved people's lives between the late 19th century and around 1940 centered around the necessities of life (food, clothing and shelter) and our homes (electricity, central heating and indoor plumbing). The post-war growth spurt was driven by early 20th century technological advances that were not made widely available because of the Great Depression and then World War II. By the 1970s the impact of these advances began to slow. Going further, Gordon forecasts that future US economic growth will be much lower because the most recent inventions and innovations will not spur growth by very much. In fact, he sees little income growth for those in the bottom 99\% of the income distribution as we move forward. Redistribution may be the main hope for a majority of the population to experience gains in their standard of living.

Another reason for slower economic growth comes from Baumol's Disease. William Baumol (1967) noted that the service sector cannot yield great productivity increases because of the nature of servicesthey require human contact and direct human input. His telling example is a horn quintet. Musicians cannot be more productive by playing faster (as takes place when productivity improves in manufacturing) or by eliminating one player (since the piece would no longer be a horn quintet). As developed countries increasingly become service economies (especially as labor leaves a manufacturing sector that requires less 
labor), this structural transformation will slow economic growth, just as the movement of labor from agriculture to manufacturing led to improved productivity growth and economic growth.

Due to these two structural changes, future growth rates will likely be lower than past growth rates. In addition, environmental concerns will require slower economic growth in order to ward off climate change (Pressman and Scott forthcoming; Victor 2008). Taking all this together, it seems that redistribution will become even more important for improving average living standards over time.

In sum, the case McCloskey makes against redistribution gets a number of things wrong. She is wrong about future sources of economic growth because there is no reason to believe that the future will be like the past and there are good reasons to believe that it will not be like the past. She is also wrong about the impact of redistribution on economic growth. Modest redistribution, returning us to post-World War II levels of inequality, should increase spending and economic growth, but not harm productivity growth very much. There should be net gains for a large majority of the population.

\section{THE MORAL QUESTION AND RELATIVE INCOMES}

Last, but not least, McCloskey (82) claims that the "focus on relative wealth or income or consumption is one serious problem" with Capital. She contends (95-97) that Piketty's moral case against inequality is that it is ethically objectionable that a super-rich woman buys a $\$ 40,000$ watch. Going further, she holds that since there is no economic argument for redistribution, the only case for it must be a moral case. To the extent that there is an economic case, it is that incomes cannot be made without social help, so large inequalities have no justification.

The previous section argued that the premise of this argument is false-there is a good economic case for redistribution. McCloskey might not like the argument, and she might not want to accept it, but that does not mean that there is no argument for redistribution.

Nonetheless, it is worth considering the ethical case McCloskey raises. For McCloskey (108) the key question is why we should be allowed to take people's income and give it to others. At the outset it is important to note that this is not what Piketty is advocating. He does not push progressive income taxation and a wealth tax to redistribute income, but rather to deal with the problem of rising inequality. Piketty (2014, ch. 16) even talks about using additional revenue to repay 
government debt, which arose because governments decided to borrow money from the rich rather than making the rich pay taxes to finance wars, national defense and social programs. McCloskey (108) is also concerned about destroying the signaling function of markets and prices with high marginal tax rates. This case is less compelling when prices are not set in competitive markets but are fixed by oligopolies. It is also less compelling since Piketty makes clear that one reason he wants a wealth tax is that the rates can be low and therefore there will be few disincentive effects (compared to raising income tax rates).

Nonetheless, McCloskey (94) is right about one thing-Piketty does not explain why inequality is bad. As noted above, there is a large literature demonstrating the negative effects of inequality. Like Piketty, McCloskey ignores this literature. Instead, her response is two-fold. First, she contends that inequality can be justified. Second, she contends that the moral problem is not inequality but poverty. We examine these two cases separately.

McCloskey (88) resorts to the Wilt Chamberlain example of Robert Nozick (1974) to justify the high incomes and high rewards received by some people. Nozick argues that if people voluntarily pay Wilt large sums of money each time he plays in a basketball game, then his earnings are justified and we should have no moral qualms about the inequality that results from this process. Taking things a bit further, one can argue that if pay is determined by how much people willingly pay others, the entire distribution of income is justified.

There are numerous problems with the Wilt Chamberlain defense of inequality. Philosophers Thomas Nagel $(1975,138)$ and Cheyney Ryan (1977, 136) argue that Nozick's case is flawed because of hidden premises in his argument-for example, that individuals have rights that may not be transgressed for any reason. Jonathan Wolff (1991) and the Arizona Law Review (1977) symposium (especially the papers by Robert Paul Wolff and George Christie) provide a more concerted philosophical argument against Nozick.

Pressman (2013) sets out a detailed economic argument against Nozick. Here a brief summary will have to suffice. Interested readers can consult the original paper for details. First, the Wilt Chamberlain example begins with an assumption that is unlikely to be true in the real world-initial distributions, stretching far back in history, are by-andlarge just. Second, there is a sort of fallacy of composition in Nozick. Wilt is part of a team. If everyone on the team gets paid by individual 
fan contributions, and if these individual contributions are all regarded as leading to fair incomes, it does not mean that the overall distribution will be fair. Empirical evidence exists that allowing people to freely contribute to Wilt would not yield results that most people take to be fair. There is also empirical evidence that it would hurt others and hurt Wilt (see again pages 152-153 above that discuss the impact of inequality on economic growth). Finally, for John Locke (1980, ch. 5) (who made the case for private property and accumulation) and for the Wilt Chamberlain example, there must always be enough left over for others at the time property is acquired. If future generations are deprived of sufficient property, the Locke-Nozick argument does not hold water.

This last point is the most relevant concerning Capital. Piketty contends that wealth has been inherited and that its growth has taken place over many generations. Wealth grows at a faster rate than incomes grow on average, resulting in the very rich (the top 0,1\%) owning larger and larger fractions of total wealth and receiving larger and larger fractions of national income. This means that, contra Locke, at some point in the process sufficient wealth will not be available for everyone else and insufficient income from wealth will go to average citizens. Consequently, the Wilt Chamberlain example, which rests on Locke's argument for the acquisition of private property, fails to justify the inequality that Piketty worries about. Without this justification, McCloskey's case against Piketty comes close to the straw man argument McCloskey herself uses against Piketty-inequality is good for McCloskey and whatever degree of inequality we find in the real world must be good.

This brings us to the last issue. If poverty is the main problem, rather than inequality, we should focus on policies to address this problem. As such, wealth taxes and other policies to reduce after-tax inequality address the wrong problem. McCloskey (99) contends that poverty rates have fallen recently and that the decline is even greater if we measure poverty correctly. To deal with any remaining poverty she proposes a basic income guarantee; she rejects higher income taxes, which she fears will harm work incentives and economic growth.

Several flaws plague this argument. First, as noted previously, Piketty's wealth tax is not intended to redistribute income. Rather, it is to slow down the accumulation of enormous wealth that then gets passed on to heirs who no longer have to work. Piketty is concerned 
about the same incentive problems as McCloskey, and proposes a global wealth tax to minimize incentive problems.

Second, it is not clear that basic income guarantees are free of work disincentives. A large basic income to mitigate poverty runs into two related problems-there is no work incentive if people receive a large guaranteed income, and higher taxes will be necessary to provide this income floor. Moreover, if the income guarantee reduces work effort substantially, the money required of everyone else to fund this program will be much greater. In brief, these are the same problems McCloskey raises regarding the tax proposals set forth in Capital. Switching from a wealth tax (and a progressive income tax) to a guaranteed income plan does not change this situation. The incentive problem has not disappeared; it still exists.

Third, it is not clear that poverty rates are falling in rich countries "recently" as McCloskey (99) contends. According to the official Census Bureau count, 27,3\% of the US population was poor in 1959 (the first year for which we have decent data using the Orshansky methodology, which uses fixed income levels to measure poverty). Over the next decade, the US poverty rate fell to $14 \%$ in 1969. Since then it has increased to $21,1 \%$ in 2014 , the last year for which we have data. The numbers do go up and down over time, based on macroeconomic circumstances as well as other variables. Still, the trend is clear-US poverty rates fell in the decade between 1959 and 1969; between 1969 and today, poverty rates have increased. At present they are more than halfway back to their 1959 level. Given this, it is hard to accept the claim that US poverty rates have fallen recently.

McCloskey is correct that poverty is not measured correctly. However, measurement errors do not all fall on one side; actual US poverty rates are not necessarily lower than what the government reports. Several factors make the official US poverty rate too low. First, there is no accounting for tax payments made by low-income households. Poverty is measured using pre-tax income. Over the past several decades higher Social Security taxes have reduced disposable income for those with low incomes, limiting their ability to purchase necessities. In addition, the Orshansky minimum food requirements (which form the basis for her poverty thresholds) were designed for emergency situations only; they provided a mere $80 \%$ of annual nutrition needs (Rogers 2000) and were never expected to provide adequate nutrition for an entire year. Yet they form the basis for annual 
US poverty thresholds. Further, as socio-economic characteristics change, family needs can also change. Child care is not necessary for most families when the family has one breadwinner and one person staying at home to care for the children. With two employed adults, however, child care becomes a necessary expense. Finally, there is the issue of household debt and the interest that must be paid on that debt. Some of this results from borrowing having replaced the government safety net as a way to protect households in difficult economic times. The problem here is that the interest paid this year on past debt cannot be used to buy basic necessities such as food, clothing, and shelter. Pressman and Scott (2010) estimate that just subtracting the interest payments on past debt (and not accounting for any debt repayment) would have pushed up the US poverty rate in 2007 by 1,1 percentage points. And this underestimation of poverty has been growing over time as household debt levels have risen.

What is true for the US is also true of other developed countries. Most developed countries do not have official absolute poverty thresholds. Instead, poverty is typically measured in relative terms. Similarly, the Luxembourg Income Study (LIS) provides relative poverty measures for many nations over several decades. The US poverty rate for individuals was 15\% in 1979 (using a poverty threshold of 50\% of adjusted household median income) according to LIS; by 2013, the US poverty rate was $17 \%$. Similarly, for the UK, poverty increased from $5 \%$ in 1969 to 9,8\% in 2010; and for Norway poverty rose from 5\% in 1979 to $7,4 \%$ in 2010 . While relative poverty rates have been constant in a few nations (and have fallen in a few), it is hard to make a plausible case that poverty rates have fallen in the developed world during the last several decades.

McCloskey (99) has one final out. She contends that if you measure income correctly, and include better working conditions, more years of education, better health care, and improved quality of goods you will see that poverty rates have fallen throughout the world. Contra McCloskey, it is not clear that more years of education should be taken into account when measuring poverty. Poverty lines are supposed to measure the income needed to survive in one year. That was what Mollie Orshansky (1969) attempted to do when she developed the official US poverty measure. If you do not have enough income you are poor, regardless of your education level. The same is true of better working conditions. Education and better working conditions do improve the 
quality of one's life. I enjoy many things as a result of the great education I have received over the course of my life. Other people enjoy working in air conditioned offices with magnificent views of the mountains or water. All of this is nice. But it does not put food on the table or a roof over people's heads. These amenities will not matter a great deal for families living below the poverty line and struggling to survive.

Last but not least, we turn to the big issue raised by McCloskey. While there is no way to resolve the dispute over whether poverty should be measured in relative or absolute terms, there are good arguments for adopting a relative definition of poverty. Adam Smith, in the Wealth of Nations, held that not being poor meant that one could appear in public without shame, a statement that Amartya Sen (1999, 71) quotes approvingly. Even Orshansky $(1969,37)$ herself thought that "poverty, like beauty, lies in the eyes of the beholder" and that poverty lines should vary over time and place. Moreover, it seems as though people care about relative incomes, and are ready to act upon these beliefs-sometimes resulting in personal loss. This is one result of ultimatum game experiments (Cameron 1999; Klasen 2008). If our goal is to increase living standards, and if inequality leads to behavior that reduces output growth (revisit the earlier discussion on the economic consequences of inequality), we should measure poverty in relative terms and care about relative poverty.

Employing a relative definition of poverty means that a focus on inequality (which McCloskey opposes) and a focus on poverty (which McCloskey supports) are quite similar. In fact, they are essentially the same thing. Both measure relative incomes, and both seek to quantify the relative position of people making very little money compared to a typical citizen. They are both about where people fit into the socioeconomic hierarchy of the nation. Or, to again quote Adam Smith, the issue is whether those with low and moderate incomes are able to appear in public without shame. This requires both a certain absolute level of income (that varies with time and place) and also an amount of income that provides a standard of living that is not too far from what is typical and regarded by most people as reasonable.

Piketty examines the top of the distribution in Capital because that is where all the action is and his measure of inequality is easy to understand, especially compared to more complex measures such as the Gini coefficient. If top earners receive a larger share of total income, and 
if this share rises because $r>g$, it follows that everyone else gets a smaller share of the pie. Putting this in slightly different terms, almost all the income gains of the past several decades have gone to the very wealthy (OECD 2014; Saez 2015). The average worker has not received any extra income from his or her greater productivity. Over a long time period, median household income has fallen and poverty has increased (in both relative and absolute terms).

\section{SUMMARY AND CONCLUSION}

Thomas Piketty has written an important book on inequality. Capital summarizes the long-term international data on income and wealth inequality that Piketty has developed over several decades. But it does more than just present numbers. It provides an explanation for rising inequality, arguably the most important economic issue of our times. It also provides a simple policy solution, an annual global wealth tax. Certainly, there are flaws in the book, including confusing capital and wealth, failing to explain the long-run empirical result that $r>g$, and proposing a policy solution that has a long history of failure and does not seem feasible economically. However, Piketty has make an important case that inequality is increasing in large part because more income is flowing to the very wealthy and that this has been going on for several decades. Perhaps most important of all, the book did hit a nerve and seems to have revived an interest in both political economy and the study of income distribution.

McCloskey has written a clever but misguided critique of Capital. She employs bad arguments dressed up in fancy prose that make them sound convincing. Her paper is filled with straw men. It misunderstands human capital and ignores both the economic and moral arguments for greater equality. On the other hand, McCloskey $(95,105)$ is right that, over a number of centuries, growth rather than redistribution has enriched people's lives. But this does not mean the future will be like the past. Even the past several decades look a lot different from the distant past.

Today, as we approach the limits of the planet to absorb economic growth, and as productivity growth and the growth of living standards slow, we cannot expect large improvements in average incomes through economic growth. As John Stuart Mill urged, we need to learn how to love the stationary state. McCloskey seems to find this morally objectionable; but nowhere does she make this case. In effect, she 
succumbs to the same moral posturing that she attributes to Piketty and criticizes him for adopting-and, as this paper argues, Piketty does not adopt.

\section{REFERENCES}

Alesina, Alberto, and Dani Rodrik. 1992. Distribution, political conflict, and economic growth: a simple theory and some evidence. In Political economy, growth, and business cycles, eds. A. Cukierman, Z. Hercowitz, and L. Leiderman. Cambridge (MA): MIT Press, 23-50.

Alesina, Alberto, and Dani Rodrik. 1994. Distributive policies and economic growth. Quarterly Journal of Economics, 109 (2): 465-490.

Arizona Law Review. 1977. Symposium: Robert Nozick's Anarchy, state and utopia. 19 (1): 2-241.

Baumol, William J. 1967. Macroeconomics of unbalanced growth: the anatomy of urban crisis. American Economic Review, 57 (3): 415-426.

Benabou, Roland. 1996. Inequality and growth. NBER Macroeconomics Annual, 11: 1174.

Benner, Chris, and Manuel Pastor. 2012. Just growth: inclusion and prosperity in America's metropolitan regions. New York: Routledge.

Bloom, Matt. 1999. The performance effects of pay dispersion on individuals and organizations. Academy of Management Journal, 42 (1): 25-40.

Bloom, Matt, and John G. Michel. 2002. The relationships among organizational context, pay dispersion, and managerial turnover. Academy of Management Journal, 45 (1): 33-42.

Cameron, Lisa A. 1999. Raising the stakes in the ultimatum game: experimental evidence from Indonesia. Economic Inquiry, 37 (1): 47-59.

Cowherd, Douglas M., and David I. Levine. 1992. Product quality and pay equity between lower-level employees and top management: an investigation of distributive justice theory. Administrative Science Quarterly, 37 (2): 302-320.

Deininger, Klaus, and Lyn Squire. 1998. New ways of looking at old issues: inequality and growth. Journal of Development Economics, 57 (2): 259-287.

Evans, Chris. 2013. Wealth taxes: problems and practice around the world. Centre on housing assets and savings management briefing paper, April.

Gerhart, Barry, and George T. Milkovich. 1992. Employee compensation: research and theory. In Handbook of industrial and organizational psychology [2nd ed.], eds. M. Dunnette and L. Hough, vol. 3. Palo Alto: Consulting Psychologists Press, 481-569.

Goldin, Claudia Dale, and Lawrence F. Katz. 2008. The race between education and technology. Cambdrige (MA): Harvard University Press.

Gordon, Rorbert. J. 2016. The rise and fall of American growth. Princeton: Princeton University Press.

Henrich, Joseph, Robert Boyd, Samuel Bowles, Colin Camerer, Ernst Fehr, Herbert Gintis, and Richard McElreath. 2001. In search of homo economicus: behavioral experiments in 15 small-scale societies. American Economic Review, 91 (2): 73-78.

Hyman, David M. 2014. Public finance [11th ed.]. Stamford: Cenage Learning.

Kahneman, Daniel, Jack L. Knetsch, and Richard H. Thaler. 1986. Fairness and the assumptions of economics. Journal of Business, 59 (4): S285-S300. 
Klasen, Stephan. 2008. The efficiency of equity. Review of Political Economy, 20 (2): 257-274.

Leibenstein, Harvey. 1966. Allocative efficiency vs. x-efficiency. American Economic Review, 56 (3): 392-415.

Locke, John. 1980 [1689]. The second treatise of government. Indianapolis: Hackett Publishing.

Lundberg, Mattias, and Lyn Squire. 2003. The simultaneous evolution of growth and inequality. Economic Journal, 113 (487): 326-344.

McCloskey, Deirdre N. 1985. The rhetoric of economics. Madison: University of Wisconsin Press.

McCloskey, Deirdre N. 1987. The rhetoric of economics: response to my critics. Eastern Economic Journal, 13 (3): 308-311.

McCloskey, Deirdre N. 2006. The bourgeois virtues: ethics for an age of commerce. Chicago: University of Chicago Press.

McCloskey, Deirdre N. 2014. Measured, unmeasured, mismeasured, and unjustified pessimism: a review essay of Thomas Piketty's Capital in the twenty-first century. Erasmus Journal for Philosophy and Economics, 7 (2): 73-115.

Mirlees, James A. 1971. An exploration of the theory of optimal income taxation. Review of Economic Studies, 38 (2): 175-208.

Nagel, Thomas. 1975. Libertarianism without foundations. Yale Law Journal, 85 (1): 136-149.

Nozick, Robert. 1974. Anarchy, state and utopia. New York: Basic Books.

Oates, Wallace E., and Robert M. Schwab. 2015. The window tax: a case study in excess burden. Journal of Economic Perspectives, 29 (1): 163-179.

OECD. 2014. Focus on top incomes and taxation in OECD countries: was the crisis a game changer? Paris: OECD.

Okun, Arthur. M. 1975. Equality and efficiency: the big tradeoff. Washington: Brookings Institution.

Orshansky, Mollie. 1969. How poverty is measured. Monthly Labor Review, 92 (2): 3741.

Ostry, Jonathan David, Andrew Berg, and Charalambos G. Tsangarides. 2014. Redistribution, inequality and growth. Washington: International Monetary Fund.

Panizza, Ugo. 2002. Income inequality and economic growth: evidence from American data. Journal of Economic Growth, 7 (1): 25-41.

Perrotti, Roberto. 1993. Political equilibrium, income distribution and growth. Review of Economic Studies, 60 (4): 755-776.

Perrotti, Roberto. 1996. Growth, income distribution and democracy: what the data say. Journal of Economic Growth, 1 (2): 149-87.

Perrson, Roberto, and Guido Tabellini. 1994. Is inequality harmful for growth? American Economic Review, 84 (3): 600-21.

Piketty, Thomas. 2014. Capital in the twenty-first century. Cambridge (MA): Harvard University Press.

Pressman, Steven. 1987. Further comments on McCloskey's argument. Eastern Economic Journal, 13 (3): 305-311.

Pressman, Steven. 2013. Justice and history: the big problem of Wilt Chamberlain. Economic Issues 18, (1): 1-16. 
Pressman, S. 2015. Understanding Piketty's "Capital in the twenty-first century". London: Routledge.

Pressman, Steven, and Robert H. Scott. 2010. Consumer debt and poverty measurement. Focus, 27 (1): 9-12.

Pressman, Steve, and Robert H. Scott. Forthcoming. Poverty and income distribution in a zero-growth world. In Handbook on growth and sustainability, eds. Victor and B. Dolter. Edward Elgar.

Ramsey, Frank 1927. A contribution to the theory of taxation. Economic Journal, 37 (145): 47-61.

Rawls, John. 1971. A theory of justice. Cambridge (MA): Harvard University Press.

Rogers, Harrell. 2000. American poverty in a new era of reform. Armonk: M.E. Sharpe.

Ryan, Cheyney C. 1977. Yours, mine, and ours: property rights and individual liberty. Ethics, 87 (2): 126-141.

Saez, Emmanuel. 2015. Striking it richer: the evolution of top incomes in the United States (updated with 2013 preliminary estimates). Unpublished paper.

Samuelson, Paul A. 1988. The passing of the guard in economics. Eastern Economic Journal, 14 (4): 319-329.

Sen, Amartya. 1999. Development as freedom. New York: Random House.

Smith, Adam. 1937 [1776]. The wealth of nations. New York: Modern Library.

Victor, Peter A. 2008. Managing without growth: slower by design, not disaster. Cheltenham: Edward Elgar.

Wilkinson, Richard G. 1996. Unhealthy societies: the afflictions of inequality. London: Routledge.

Wolff, Jonathan. 1991. Robert Nozick: property, justice and the minimal state. Cambridge: Polity Press.

Zak, Paul J., and Stephen Knack. 2001. Trust and growth. Economic Journal, 111 (470): 295-321.

Steven Pressman is professor of economics at Colorado State University, in Fort Collins, Colorado, and emeritus professor of economics and finance at Monmouth University in West Long Branch, New Jersey. In addition, he serves as North American editor of the Review of Political Economy, and as associate editor of the Eastern Economic Journal. His main research areas are poverty and income distribution, post-Keynesian macroeconomics, and the history of economic thought. Over the past three decades, Pressman has published more than 150 articles in refereed journals and as book chapters, and has authored or edited 17 books, including Understanding Piketty's Capital in the 21st century (Routledge, 2015). A new guide to post keynesian economics (Routledge, 2001), Alternative theories of the state (Palgrave Macmillan, 2006), and Fifty major economists (Routledge, 2013), which has reached its third edition and has been translated into five different languages.

Contact e-mail: <pressman@monmouth.edu> 